\title{
Pragmatic approaches to intercultural ethics: The basis for fostering communication among nationalist groups
}

\author{
Maria del Mar Llera \\ Department of Communication, Sevilla University \\ C/ Bolsa, 36, Ático, Sanlúcar de Barrameda (Cádiz) D.P. 11540, Spain \\ e-mail: iam_mariaspanish@yahoo.com
}

\begin{abstract}
This research is part of a more extensive programme that deals with intercultural ethics from different perspectives. All of them share a common inspiration sprung from UNESCO's Intercultural Ethics Project. The main goal of this paper consists in offering pragmatic/theoretical tools in order to analyse a cultural and political issue which is currently very important in Spain: the confrontation between those promoting Spanish national culture and those promoting the Basque one. I approach this confrontation in terms of discursive praxis, reaching the conclusion that only if both groups are capable of self-understanding will they be capable of reciprocal-understanding, and only then will it be possible to maintain peace in our country.
\end{abstract}

This essay is part of a research project inspired by some prominent initiatives of UNESCO on ethics and intercultural dialogue in the globalisation framework (Unesco 2001). ${ }^{1}$ It also expresses my interest in the world present from the perspective of the semiotics of culture, analysis of speech acts and political thought.

In the first phase of this project, while reflecting upon the need and the real possibilities of grounding an intercultural ethics, history reminded me of the innumerable occasions when the West has contacted other peoples, which has yielded relevant fruits: on the one hand, domination, but on the other, encounter, thought and institutionalisation of ways of intercultural communication (Llera 2000a). Later

See also http://www.unesco.org/opi2/philosophyandethics/ (The Universal Ethics Project). 
on, the analysis of globalisation in its economic aspects, and the urgency of setting out ethical basis for development, led me to investigate the speeches of some international financial institutions (mainly, the International Monetary Fund and the World Bank). In them I discovered not only power interests, but also signs of reasonableness which I interpreted as a token of a minimum consensus, although precarious, in the realm of values (Llera 2000b). In the third phase of my project, some months before the events of September 11, 2001, in the United States, I decided to undertake a study on the role played by religion in the international political context, carrying out a critical reading of Samuel P. Huntington's book upon the clash of civilisations. Actually, my goal was to discover what could have avoided such a disaster (Llera 2001). In the fourth phase of my project, where this essay is included, I am intending to offer a set of adequate pragmatic/theoretical tools to analyse a cultural and political issue which is currently very important in Spain: the confrontation between those promoting Spanish national culture that draw together the Spanish State above the peripheral nationalist groups and those who adopt the inverse position. Concretely, I will focus on the defenders of the Basque nationalist culture.

Since the issue has a textual character, it will be approached from the semiotics of culture and contemporary political thought. Thus, the first section of this paper elucidates the most interesting interpretations of the notion "culture" that illustrate the academic debate. Subsequently, the genesis of the concepts "nation" and "nationalism" is briefly reconstructed in order to understand the nature of cultural nationalism and its relation to political nationalism. Upon these bases, the most significant guidelines of the Spanish and Basque nationalist speeches are drawn in reference to their respective historic origins: political, economic, social and cultural. The issues posed by such speeches are leading me to interpret them from a dialectical point of view as an expression of a disjunction between the universalist and the communitarian position that characterises contemporary political thought. In order to diminish the conflict - or at least to integrate it in the framework of a deliberative democracy - I suggest various approaches which are the result of the most recent investigations in intercultural communication. Finally, I am going to carry out a critical evaluation and sketch some pertinent conclusions. 


\section{Concepts of culture}

History has welcomed the twentieth century as one of enormous scientific and technical progress. However, it is not usually considered that the importance of such achievements stems from its cultural and social expanse, its capacity to improve human life while cultivating it. Our time should also pass into history as the Century of Cultures (in plural). The discovery of other cultures - intercultural encounter and communication - has been a kind of contemporary event as - or even more - important than scientific discoveries. Nonetheless, this dynamic has not only been influenced by positive factors; in the roots of such phenomena, besides an unprecedented development of new communication technologies, a boundless political and economic ambition on the part of the States and the large financial corporations has been manifested. Colonial imperialism, fostered by capitalist requirements, has transformed the world into a global whole, an asymmetrical system of interrelation, exchange and interdependency, which is structured according to the dominion "logic".

Nevertheless, the same factors that have given rise to a relationship of domination have also left some chances for a relationship which respects both equality and difference, making a true encounter possible. The homeostasis of the colonial system itself has fostered striking breakthroughs in anthropological, ethnological and social sciences since the beginning of the twentieth century as the contributions of Émile Durkheim (1960a; 1960b), Franz Boas (1938; 1955; $1965 ; 1982)$ and B. Malinowski $(1923 ; 1948)$ have shown, to cite just a few outstanding names. With these authors the West began to deal with non-Western peoples and their cultures not only as objects of economic exploitation, but also as objects/subjects of scientific research, humanistic reflection and social preoccupation. At the same time, cultural studies started to develop from semiotics, mainly the structuralist one following the trail of Claude Lévi-Strauss (1958; $1962 ; 1964-1978 ; 1967)$, as well as that of Louis Hjelmslev or Juri M. Lotman (1996; 1998). Simultaneously, the School of Birmingham ${ }^{2}$ and the School of Frankfurt (Marcuse 1969; 1972) established the basis for all further investigation in this field.

Currently, the background of the afore-mentioned contributions and the extension of global communication networks, are bringing

2 Cultural Studies and Sociology Department. 
about an increasing number of essays and systematic investigations on the concept of culture with reference to multicultural contemporary societies which are connected through the media. All those studies provide a range of definitions of "culture", and we are going to highlight some of them as analysis tools.

First of all, let us recognise that every culture can be approached from a speculative or an empirical perspective. In the first case there is a possibility for a prescriptive and an ethical processing. In the second one, a descriptive point of view and a positive scientific method prevail. However, as it is not easy to avoid an ideological bias in describing cultures, it is harder to avoid it in analysing and criticising them. The manipulation of historical-cultural studies in order to promote an ideological position is not just frequent, but normal, from the premise that there is no culture without ideology (Habermas 1982) and consequently every ideology is a cultural expression or vice versa (Barthes 1957). "There is no way out of the game of culture" (Robbins 2000: xi). Every appearance of neutrality becomes hypocrisy or fiction, which is as legitimate or illegitimate as the ideological fiction itself, supposedly rejected by neutrality.

The ideological meaning of culture is usually linked to a mythical concept and therefore to collective imagination, legend or literary creation. Culture amounts to memory, the past. The arcane and legendary past. Or perhaps historic, verifiable: lived experience. Perhaps, self-consciousness. ${ }^{3}$ In any case, culture is remembrance heritage. It lives thanks to tradition, it coins custom, it implies continuity.

But every tradition is mediated in a hermeneutic way; it is fed by interpretation, through which it is connected with the present, providing it with a meaning which is aiming at the future. Thus, culture becomes actual as a collective way of life, organisation, thought. It is a fact. Or a concept? It is reality, but also representation, and even invention... It is the discovery of specific objective structures which are actually there, as well as their always on-going reconstruction. Cultures are discovered; this implies that they exist as a matter of fact but also as a result of creative activity, since every discovery is invention. Moreover, cultures have to be brought up to date, in order to keep on existing. That is to say, to stop existing as they were, to

3 "A nation is a community of people who consider themselves to be a nation" (Seton-Watson 1977: Nation and States. Boulder, Colorado: Westview Press). Cited by Heiberg 1989: ix. 
change them, to adapt them constantly to the times. A culture which is not able to adapt, dies.

In this way, culture is power and liberty. Imposition, control. ${ }^{4}$ Creativity and genius: it is Volksgeist, the spirit of a people. But a spirit... which is materially conditioned. Every culture is a product and works as an exchange value: as merchandise. Since it is bought and sold, it is not just intangible: it can be consumed. It has an instrumental dimension; so it is a means. Actually, there are cultural industries. And also cultural policies, either liberalising or protecting, because culture must be protected as an expression of identity or substantial essence. But in this sense, culture is an end, it may not be reduced to a means category; it may not be marketed. This is precisely why is one of the State's responsibilities.

Every culture shapes values, mints norms, proposes ideals and is embodied in institutions. It represents a collective position which involves its respective opposition: it draws its own borders, it differentiates itself from otherness. And this is exactly why it relates to otherness. Talking about one's own culture implies talking about alien ones; to be defined as a member of a cultural community means to be referred to others, to those from whom oneself differentiates. Every culture is open in some way, it is permeable, hybrid. To affirm a "pure culture" is a contradiction in terms.

Culture integrates all that has been represented, said and thought in a social framework. But it also consists of the hidden or concealed things, the non-said, the non-thought background upon which speech and reasoning are shaped. Culture is simultaneously conscious and unconscious; therefore it becomes impossible to be translated, it is immeasurable. It can never be completely submitted to the control of the will. However, in itself it is a necessary condition for a people's willing self-determination. According to this, every culture justifies itself as an expression of liberty; nobody has the right to judge it from the outside. Nevertheless, it always includes some self-destructive and therefore illegitimate - aspect.

The nature of culture, as that of every human thing, is complex, dialectical. It can be conceived in very different ways. My explanation has

4 "To create a nation involves a dramatic substitution of diversity with uniformity. [...] People who felt themselves to be culturally distinct and distant must be transformed into a community bound by cultural affinity and solidarity. (...) An array of divergent traditional loyalties must be ruptured, reshuffled and redefined in order to fuse neatly around the boundaries of this community" (Heiberg 1989: ix). 
intended so far to underline such plurality, paradoxically connecting opposite perspectives and weaving a dialectical but coherent discourse.

\section{Nation and nationalism}

According to the specialists, nationalism is a typical product of Modernity (Habermas 2001b: 621) linked to Enlightenment philosophy, bourgeois revolutions and Romanticism (De Blas 1997). ${ }^{5}$

However, the term "Natio" means birth (Suárez 2000: 15) and dates from classical Antiquity, naming "communities of origin geographically integrated because of settlement or neighbourhood, and culturally integrated because of a common language, customs and traditions, but not yet politically unified in a State organisation" (Habermas 2001b: 622).

During the Middle Ages, "nation" expressed both belonging to a specific community and the place of origin. This meaning was spread in the emergent universities, which grouped the students according to their origins (Suárez 2000: 15). This is why the word points to a political structure: that of Kingdom or Crown.

As we said previously, in the Modern Age the term "nation" acquires its current meanings, linked to either State nationalism or peripheral nationalism, self-determining or secessionist.

Since the French Revolution, the pre-political meaning of the word was put aside, coming to designate a constituent element of the citizens' political identity in a democratic community (Habermas 2001b: 622).

In the Romantic period, this new sense inspired Ernest Renan's famous sentence: "Une nation est donc une large solidarité, [...] elle se résume par le consentement, le désir clairement exprimé de continuer la vie commune. L'existence d'une nation est un plébiscite de tous les jours". 6 Renan did not affirm that the essence of a nation lies in a community of descent, of ethnic-cultural links, but rather in a political community of citizens actively engaged with their self-government. However, both meanings live together in the German mentality.

5 See the articles "Fichte", "Herder", "Revoluciones liberales y nacionalismo", "Romanticismo y nacionalismo".

6 Renan, Ernest 1882. Qu'est-ce qu'une nation? París. Cited by Gellner 1989: 19. 
Herder, Fichte and Hegel enlarged on that concept, marked by the influence of Kant's doctrine on self-determination.

Herder $(1966 ; 1967 ; 1975 ; 1979)$ was one of the first defenders of the rights of a nationality which is determined by linguistic frontiers. This constitutes a patrimony of wisdom both in civilised peoples and in the badly-named "barbaric" peoples, which have cultivated natural religion and poetry instead of rationalism. The relation among the collective spirit of a people, its thought, its feeling and its language inspired every romantic requirement of cultural nationalism from Herder on, even encouraging criticism of colonial imperialism.

Fichte's Reden an die deutsche Nation $(1938 ; 1971)$ has fostered radical German nationalism, based on a metaphysical conception of the "Germanic" as a distinctive essence of their people, where language plays a main role. From that essence derives the universal mission of the German nation, which has revealed their spiritual greatness by building a State which fits in it and grounds its law upon the right to equality of liberty that is possessed by every citizen. Therefore, the German nation does not stem from politics, on the contrary, it is itself who gives birth to politics.

According to Hegel (1982), universal history unfolds in a spiritual realm which reveals the Idea and the self-consciousness constituting an individual whose character is at the same time universal and concrete, namely, constituting a people. In history, spirit is the spirit of the people. Its being, objectivity and substantial reality is always becoming. Spirit is essentially the result of its self-constituent activity, of being known to itself. Spirit is produced and carried out according to its knowledge about itself; it aims what it knows about itself to be carried out. Moreover, it tends to focus on itself and to exist for itself. That is liberty, spirit's main aspiration, which is reached by denying continuously every threat against it. Universal history comprehends the whole of this process and includes the spirit of all different historic peoples, because the fruit of every people's life is not to remain in it. On the contrary, it requires its annihilation, so that other peoples be born, assuming and overcoming the particular being towards the universal being. 


\section{Cultural nationalism and political nationalism}

K. Meinecke was one of the first authors to explicitly clarify the distinction between the concepts "cultural nation" and "political nation" (De Blas 1997: 337-339). The former is tied to ethnic-linguistic characteristics; the latter, to the State construction. A cultural nation is original, is spontaneously born from a historic community of race, language, territory, traditions and life. A political nation is the fruit of a desire for power, a controlling and homogenisation strategy. All political nations adduce some cultural roots to be legitimate; most of cultural nations claim political power and in the long term their own State. Consequently, the relation between cultural nationalism and political nationalism is both contrasting and complementary.

An attentive study of modern and contemporary nationalism reveals the impossibility of recognising a cultural and ethnic homogeneity from the basis of the non-Western States born from decolonisation. But strictly speaking no State, even European, can be free from criticism since a great diversity, a cultural plurality of nations lies at the roots of every national State. This is a matter of fact even though that plurality fits inside a common national culture. In short, we should be aware that the political factor never remains on the margin of culture construction and in this sense every nationalism has political roots.

\section{The spanish nationalist discourse}

Against the more and more frequent reduction of Spain to the State category, solid arguments are supporting Spain as a nation in a prepolitical sense, such as claimed by cultural nationalism (Real... 2000). Its roots date from the age of Roman domination, where the diocese of Hispania constituted an ever-increasing political unity, until its emancipation was achieved by the Visigothic monarchy, which in the fifth century A. D. consolidated the political unity of the territory for the first time in history.

The Islamic invasions split up the Hispanic monarchy, establishing Al-Andalus. However, for 500 years the Reconquest expressed "a tightened vital and spiritual bond during the whole of the Middle Ages, a common sensibility and emotional capacity. The idea of unity 
is present in all writers of the Middle Ages" (Rumeu de Armas 2000: 245).

From the ninth century four Christian kingdoms were established in the Iberian peninsula: León, Castilla, Navarra and Aragón, besides the County of Barcelona. Barcelona later joined the kingdoms of Aragón and Valencia, although in a federative framework because of their linguistic, institutional, and historic differences.

The final union of the distinct kingdoms was performed between the centuries fifteenth and sixteenth, once Castilla and Aragón were unified through the marriage of Isabel and Fernando. The conquest of Granada and the annexation of Navarra perfected that unity. The colonisation of America consolidated and extensively projected that nationality. Since the War of Independence, most scholars apply the concept of nation to Spain as a singular entity. "A nation is a reality which can be verified and perceived in itself" (Rumeu de Armas 2000: 246). "A nation is a matrix whose political structure is a State" (Rumeu de Armas 2000: 247).

At the end of the nineteenth century the liberal State of the Restoration (Jover 2001: 350-358) was promoting a central nationalism to cope with the incipient peripheral nationalisms, affirming the sovereignty of the Spanish nation and the equality of liberties and rights against regional particularities.

Since then the Spanish State has been defined as a Nation-State according to the modern political paradigm. The second Article of the Constitution currently in force makes this statement: "The Constitution itself is grounded on the indissoluble unity of the Spanish Nation, common and indivisible country of all Spaniards; recognising and guaranteeing the right to autonomy for nationalities and regions that are integrated in it, as well as solidarity among all of them".

However, during the genesis of our Constitution, the debates that developed in the Constitutional Commission threw into relief the problematic character of this formulation defining the Spanish nation from extra-constitutional patterns: "A nation exists before and above the Constitution" (Cotarelo 1992: 195). That is to say, the Spanish nation is treated as a matter of fact which is previous to constitutional law and, consequently, as a cultural nation rather than a political nation.

On the other hand, "the right to autonomy is recognised and guaranteed". But this autonomy should be interpreted in the framework of the national unity, which has just been stated. It should not be mis- 
understood as the sovereignty that belongs only to the Spanish people, from which the powers of the State are emanating, according to the first article of the Constitution in its second paragraph. Therefore the Spanish people are not described in any way as an aggregate of ethniccultural communities, but as an aggregate of individuals, of citizens.

The Constitution is not placing the Spanish nation at the same level as the autonomic nationalities. The Spanish nation is considered a cultural historic community that supports and legitimates the State's political organisation, including the Constitution itself. It is a unique and original social structure, holding sovereignty ${ }^{7}$ that is affirmed as indivisible. On the other hand, the autonomic nationalities are described as parts of the Spanish nation showing off autonomy in the framework that was designed by the constituent power. Thus, the statutes of autonomy do not recognise any political-legal regional power to have an original character, but just to be drawn from the State. Besides the nation which is supporting it, the State is the common political space that covers all the regional communities, as well as the prevailing object of the political loyalty (Solozábal 1997: 339-341).

However, nowadays it is clear that the development of the Constitution has led to an "evident disparity among the diverse cultures of the different communities" (Laín 2000: 253). Such appreciation, together with the affirmation of the Nation-State as a "prevailing object of the political loyalty" has recently induced the Spanish Government to promote a "constitutional patriotism". Thus it is expressed by the title of one of the papers which was presented at the fourteenth National Congress of the Popular Party, ${ }^{8}$ provoking more expectation and polemics.

The politicians who were responsible for the paper - the PP President in Guipúzcoa, María San Gil, and the Secretary of State, José Piqué - declared to offer "a positive concept of patriotism, passionate for liberty and tolerance, praising the value of living together despite profound feelings of belonging".

7 On this point the debate on the differences between national sovereignty and popular sovereignty is not taken into account, since the Constitution states that "national sovereignty resides in the Spanish people" (Article I, paragraph $2^{\circ}$ ).

8 Held in January 25-27, 2002.

9 All quotes are taken from the web site of the Popular Party: www.pp.es (December 2001). 
The paper did not combat peripheral nationalism, but it strove to achieve "reconciliation" after the "failures to meet up" that have been provoked by a concept of Spain from which "only those who reckon their confrontation to Spain to be the reason for their existence may be excluded".

José Piqué, anticipating the content of its intervention, affirmed that Spain is "a magnificent platform for all to live together despite profound feelings of belonging, and respecting the value of liberty". It is clear that the plurality of Spain cannot be contemplated just as a "problem", but as something that is "constituent".

According to Piqué, constitutional patriotism is a feeling of pride that is "rational and critical, not based on myths of the past, ethnic purity, romantic feeling or rural mysticism". It reaffirms the full force of the constitutional pact, through which "we came to an agreement establishing the basis of living together in liberty".

\section{The basque nationalist discourse}

In spite of its respective divergences, foralism ${ }^{10}$ is often founded in the origins of Basque nationalism.

Throughout the centuries foralism has meant an effort to defend the Basque province's institutions and historic privileges against the central power. Such prerogatives date back to the Early Middle Ages, when the Crown of Castilla offered the hidalguia to all Basques, giving rise to a unique social class and an equalitarian society in that respect, although economic differences among its members always subsisted.

Some interpreters think that such a historic situation expresses the Basque people's original sovereignty, willingly delegated to make an agreement with the Crown. On the contrary, other authors state that this shows the secular roots of the subordination of the Basque people regarding a superior political entity, that would become Spain later on.

Dispensing with such debate, it seems reasonable to affirm that the defence of the statutes supposed a form of pre-nationalism, developed by clergymen and lawyers from a theoretical perspective. This posi-

\footnotetext{
10 This comes from the word "fueros", which names the whole of the historic laws, privileges and particular institutions belonging to certain Spanish provinces since the old ages.
} 
tion was shaping a political sub-culture throughout the centuries until a common tradition was forged, reinforced by the singularity of the Basque language. Such tradition, whose roots were rural, referred to archaic and religious values, drifting in some way towards fundamentalism. Foralism minted its own myths reflecting the Basque people's aristocratic, heroic or biblical genealogy.

However, fighting for foralism was usually compatible with a feeling of belonging to a superior political entity until the Carlist defeat in 1872-1876 war, which questioned this attitude. Then the Spanish Monarchy revoked the Basque statutes, which had been recognised through the Vergara Agreement at the end of the first Carlist War. Such abolition provoked a sharp feeling of aggression. Moreover, a social crisis arose because of the progressive industrialisation of Vizcaya and the exploitation of the Somorrostro mines, causing the massive arrival of immigrants coming from other Spanish regions. The modernisation and the growth of towns, as well as the increasing liberalisation of customs began to deeply transform the society. Thus, the Basque people turned back upon itself, giving rise to its cultural Renaissance at the beginning of the twentieth century.

From then on, manifold associations and cultural magazines designed for the promotion of the Basque culture were born. In this way, an idyllic image of rural life and traditions was arising against modernisation and liberalisation, which the most conservative people thought as moral degeneration, uprooting and loss of identity. In addition, at that time an epic story was diffused about the Basque people struggling for their rights and patrimony against the Spaniards, who were considered as foreigners.

The rejection of industrialisation and the desire for maintaining and revitalising the Basque traditions, as well as its language, were to give birth to the foundation of the Basque Nationalist Party (BNP) by Sabino of Arana-Goiri in 1895. Arana was brought up in a foralist and Carlist atmosphere. Although he soon rejected it, he always remained linked to it in diverse ways, as illustrated by his motto: Jaungoikoa eta Lagizarra. $^{11}$

The evolution of Arana's ideology is usually analysed according to three different phases.

11 Jaungoikoa means "God". Lagizarra means something more than just the Basque statutes, it includes the whole of the Basque institutions, written and unwritten law, customs, race and language (Fernández Sebastián 1997: 182). 
The first one (1893-1898) is aggressively traditionalist, fundamentalist and contrary to Spanish centralism, liberalism, socialism, industrialisation and modernisation. Arana praises the Basque people because of their race and religion. He does not hesitate deforming the historic reality in order to exalt liberty and sovereignty of the Basque nation against Spain, and to claim its independence.

The second phase of Arana's evolution (1898-1902) is characterised by pragmatism. Arana is elected as a Vizcaya deputy, and this is why he becomes more realistic, less fierce in his criticisms of industrialisation, ${ }^{12}$ more open to Basque autonomy, which was previously rejected. At that time, Basque nationalism was split forever because of the divergence between those struggling for independence and those struggling for autonomy: the former were radical aranistas (many of them coming from the ranks of fundamentalist Carlism); the latter, euskalerríacos (moderated bourgeois or liberal foralists, members of the Bilbao Euskalerria Society).

The last year of Arana's life (1902-1903) was characterised by a U-turn, defending the widest autonomy for the Basques inside the Spanish State.

The first BNP National Assembly was held in 1906, publishing a manifesto programmed with its own marks of identity, which would be maintained until 1966. It emphasised the objective of reaching a full foral reintegration, maintaining and reshuffling the Basque traditions, language and racial identity. The goal of independence was never mentioned, despite Arana's proposal at the beginning of his ideological evolution, since the pragmatic or moderate sector led by Ramón Sota and Engracio Aranzadi Kizkitza achieved dominance. In this way the project of a Statute of Autonomy inspired by Catalonian nationalism was forged.

In 1916 the BNP was transformed into Nationalist Communion, expelling all its members who opted for independence. Shortly, an aberriano $^{13}$ BNP was to be born from the expelled group, led by Eli Gallastegi and Manu Egileor. In 1930, at Primo de Rivera's fall, the party reunification was achieved, with the exception of a progressive sector - left wing, not aranista - that would give rise to the Basque

12 Actually, the BNP consolidation was achieved thanks to the support of Ramón Sota, an important industrialist from Vizcaya, who contributed part of his fortune to the Basque nationalist project.

13 Which is expressed through the weekly magazine Aberri, whose meaning is "homeland". 
Nationalist Action. In 1931, the BNP was provisionally allied with the carlistas, but promptly broke with them to fight for the Statute of Autonomy. The dissidents gathered round the weekly magazine JagiJagi claimed for the independence, but they did not achieve sufficient support to constitute a Basque National Front aiming at that goal. In October 1936 the Statute of Autonomy was approved by the Second Republic Government, at the franquist rising.

In 1966 when the BNP renewed its political programme for the first time since its foundation as a party, the thesis for independence kept on being marginalized. Then the goal was going to be the restitution of the Statute of Autonomy ${ }^{14}$ which was revoked by the franquist dictatorship, declaring illegal the BNP public activity and encouraging indirectly the reaction of a radical nationalist sector: the abertzale left wing derived from the Jagi-Jagi group. The terrorist association ETA was born from this political movement in 1959.

The transition from Spain to democracy after the death of Franco in 1975 allowed the BNP to be rehabilitated by the Madrid Government, who favoured it to the detriment of the abertzale left. ${ }^{15}$ Since then, the PNV has showed off the hegemony of Basque democratic nationalism, despite Eusko Alkartasuna's split in 1986 and the harassment of the radicals.

A great deal of the BNP's success has been achieved thanks to its controversial policy of alliances, lacking ideological coherence. Its objective has been to reach maximum power. According to certain sectors, this manifests a common will "to liquidate the political project of the abertzale left" fighting for independence, shared by the governments of Madrid and Paris. ${ }^{16}$ According to others, it is not the case, but just the contrary.

\footnotetext{
14 From http://free.freespeech.org/askatasuna/docs/pnv.htm (December 2001).

15 During the democratic period the abertzale left wing was split into two different sectors: one of them abdicated to the armed struggle and approached reformism and the Statute option, giving rise to Euskadiko Ezkerra; the other one kept on justifying violence on behalf of the independence struggle. Herri Batasuna, linked to military ETA, comes from the latter.

16 From http://free.freespeech.org/askatasuna/docs/pnv.htm (December 2001).
} 


\section{Universalism vs. communitarianism}

In the previous sections we have reconstructed the historic origins of the Spanish and Basque nationalist discourses, which revealed a contrast to be analysed through some concepts of contemporary political thought: universalism and communitarianism.

Every universalist trend of thought affirms the existence of principles, norms or values going beyond every specific border, both individual and communitarian, to express the nature of human reason, the dignity of its personal being or some other basis not to be reduced to contingent conditions (Apel 2000; Habermas 1999; 2000; 2001a; 2001b).

On the other hand, the communitarian focus their attention precisely on those conditions, because they consider that principles, norms and values are related to particular historic communities that provide them with meaning through their hermeneutic and discursive praxis (Rorty 1989; 1991; 1998; 2000).

Since universalism states those principles which form the foundation of the democratic-liberal State of Law and communitarianism claims the particularities of a specific cultural tradition, it can be supposed that the Spanish nationalist discourse is universalist, while the Basque nationalist discourse is communitarian.

However, we have just explained that Spanish nationalism does not have just a political character, but also a cultural character. Moreover, Basque nationalism, basically cultural, has become a political nationalism, above all with the arrival of democracy.

Due to this, some coincidences may be glimpsed in the same areas where only confrontation seemed to be present. Besides, it can be noticed that those coincidences are manifested even through mistakes, because there are indications that neither the Popular Party nor the Basque Nationalist Party are sufficiently aware of the implications and the theoretical-practical extent of their respective discourses. The former does not keep in mind the dialectical and complex character that has cultural nationalism being used as a means for selflegitimisation. In addition, the Popular Party should go more deeply into the political theory about "constitutional patriotism". The BNP does not sufficiently respect the social-cultural diversity of the community that it represents, playing too much with ambiguity and underlining what is separating the Basques from Spain more than what unites them. 
The limitations of Spanish nationalism date back to its origins, in the age of the Restoration. At that time the Spanish Government did not know how to carry out an efficient project to strengthen Spain as a Nation-State due to a poor articulation in the political, cultural, and economic fields at a national level. The regional imbalances, of structural character, hindered a complete and coherent modernisation (Jover 2001: 353; Uriarte 2002: 109-132).

Currently, the Spanish nationalist discourse about "constitutional patriotism" is requiring more theoretical explanation. This concept has been the object of a complex elaboration in Habermas's work, concretely in his theory upon the deliberative politics in a post-national society.

In Habermas constitutional patriotism "does not need to be supported in any way by a cultural, linguistic, and ethnic origin common to all citizens". "A state with a homogeneous national population has always been a fiction" (Habermas 1998: 91) which has been fed by the instrumental use of the historic sciences to satisfy the need for legitimisation. "The national State itself is the one which engenders those autonomist movements in which oppressed national minorities are fighting for their rights. Submitting the minorities to a central administration, the national State is contradicting its own self-determination premises" (Habermas 1998: 91). Actually, constitutional patriotism "sharpens the sense of plurality" (Habermas 2001b: 628) recognising the different communities' particular claims.

Habermas thinks that at present a significant break between citizenship and national identity is happening, which shows that "the classical form of the national State is dissolving" (Habermas 2001b: 620-621) and that it is necessary to develop new collective identities of post-national character.

In this context, constitutional patriotism guarantees a commitment with the fundamental rights, values and principles of the democraticliberal State of Law, which have not just a national, particular o communitarian extent, but a universal one. "Suffice it to remember the European integration, supra-national military alliances, interdependency in the world economy [...]. There is no longer any alternative to the universalist valuing orientation" (Habermas 1998: 117).

Nevertheless, this commitment to universality will have to be translated into the particular traditions of the communities accepting it (Habermas 1998: 111-121). Each community of citizens should consider the value of its own tradition as relative from the perspective of 
other traditions, in order to critically appropriate its own tradition and integrate it into a common cultural framework at a supra-national level (Habermas 2001b: 628).

On this point the possibility of connecting the communitarian claims with the universalist claims may be noticed. In the same way the State has the ethical obligation to recognise national particularities, which are expressed in its territory, so nationalist communities should be capable of transcending their own limits to recognise a universal horizon that could precisely guarantee their particularities. At least, not to fall into the trap they are denouncing: the imposition and annulment of differences, since no community is culturally homogeneous.

\section{Intercultural communication}

After having found a link among the different positions which have been presented in this essay, let us develop some premises that allow the diverse nationalist cultures living together in Spanish territory to understand each other. We are going to take a look at some recent investigations in intercultural communication (Rodrigo 1999; Silveira 2000; Kymlika 1996; Bartolomé 1998).

The first section of this article reviewed the most interesting forms of understanding the term "culture", showing its complexity and manifold meaning, and even its contradictory, dialectical character.

Every culture represents a way of existing, an idiosyncrasy, a specific identity, but at the same time, a relation with everything from which itself differentiates. To say it another way: there is no culture without intercultural communication.

At the roots of every culture there is a relation with other cultures, in their most diverse modalities: learning, adaptation, acculturation, assimilation, hybridising, racial mixing, integration... The limit of that relation comes from the capacity to maintain the cohesion of the group whose identity is being defined.

This is why the definition of one's own cultural identity should be understood rather as an intersubjective need for sense than as an unquestioned and objective reality. Every collective group affirms its identity in order to legitimate, to reinforce its power or to resist an alien power, to be existentially projected, to be appropriated of its roots and to redefine them; but that praxis, which has mainly a 
discourse character, is valid only in a relative way, deriving from its functionality.

Certainly, there are no exclusive and pure identities: a plural set of identities lives together in every collective group, to be harmonised according to value scales through a democratic consensus. At the roots of such a consensus there should be not just tolerance, but the conviction that diversity is enriching and therefore that the disappearance or the alignment of any culture diminishes all the others.

Any perspective should be recognised as limited and should remain open to other possible angles, integrate them or at least carry out a continuous self-critical review. This task requires accepting certain levels of distortion and ambiguity in the communicative exchange, setting just a minimum for understanding.

Multiculturality is a fact in every society and in every State. Interculturality is a challenge. To cope with it, a specific type of communicative praxis is necessary, which is not dominated by the "logic" of power, but by the rationality of reciprocal understanding.

\section{Critical balance and conclusions}

This essay has examined the conceptual and historical basis of nationalist groups, both those that intend to legitimate the modern State and those confronting it for the rights of some particular community. Concretely, Spanish and Basque nationalism have been focused on.

The main conclusion of this essay is that the current conflict between both nationalist groups requires a deeper self-understanding on both sides. Only if each nationalism is able to understand its own premises, will it be able to understand the other and to communicate. The on-going academic reflections upon intercultural communication may be extremely useful in this respect.

Recognising the semantic ambiguity, complexity and even dialectics which characterise the diverse concepts currently in force using the terms "culture" and "nation", as well as studying the historic evolution of Spanish and Basque nationalism, may show that none of them has the right to adopt a dogmatic or exclusive attitude.

The investigation carried out so far demonstrates that both Spanish and Basque nationalism share common features, even if the former has mainly a political character, while the latter emphasises the cultural dimension. Spanish nationalism, which is promoted by the State 
institutions, appeals to an ethnic-cultural realm that includes linguistic, historic, territorial... and traditional aspects. Basque nationalism, which is ethically and culturally rooted, has always striven to open political ways to its requirements. Therefore, both types of nationalism meet from inverse but complementary positions.

Their complementary character may be noticed in a clearer way if their universalist and communitarian dimensions are considered. Values, principles and norms ruling the democratic-liberal State of Law have a universal extent but they acquire a concrete meaning only from the cultural traditions of the communities accepting and putting them into practice. This is why they are reciprocally necessary; hence the effort of the Spanish State institutions to affirm the existence of a legitimising national community and the parallel need for the Basque nationalist community to consider their own demands as relative and to submit them to universal values, principles and norms.

\section{References}

Apel, Karl-Otto 2000. Globalization and the need for universal ethics. European Journal of Social Theory 3(2): 137-156.

Barthes, Roland 1957. Mythologies. France: Éditions du Seuil.

Bartolomé, Miguel Ángel; Barabas, Alicia (eds.) 1998. Autonomías Étnicas y Estados Nacionales. México: Instituto Nacional de Antropología e Historia.

Boas, Franz 1938. General Anthropology. New York: Heath.

- 1955. Primitive Art. New York: Dove.

- 1965. The Mind of Primitive Man. New York: Free Press.

- 1982. Race, Language and Culture. Chicago: University of Chicago Press.

Cotarelo, Juan 1992. Valores y principios de la Constitución de 1978. In: Cotarelo, Ramón (ed.), Transición política y consolidación democrática: España (1975-1986). Madrid: Centro de Investigaciones Sociológicas, 163200.

De Blas Guerrero, Andrés (ed.) 1997: Enciclopedia del nacionalismo. Madrid: Tecnos.

Durkheim, Émile 1960a. De la division du travail social. 7th ed. Paris: Presses Universitaires de France.

- 1960b. Les formes elémentaires de la vie religieuse: Le système totémique en Australie. 4th ed. Paris: Presses Universitaires de France.

Fernández Sebastián, Javier 1997. Foralismo y nacionalismo vasco. In: De Blas Guerrero, Andrés (ed.), Enciclopedia del Nacionalismo. Madrid: Tecnos, $180-184$.

Fichte, Johann Gottlieb 1938. Reden an die deutsche Nation. Stuttgart: Alfred Kröner. 
- 1971. Fichtes Werke. Band 6. Zur Politik und Moral. (Fichte, Immanuel Hermann, ed.) Berlin: Walter de Gruyter.

Gellner, Ernest 1989. Cultura, Identidad y Política: El Nacionalismo y los Nuevos Cambios Sociales. Barcelona: Gedisa.

Habermas, Jürgen 1982. Conocimiento e Interés. Madrid: Taurus.

- 1998. Identidades Nacionales y Postnacionales. 2nd ed. Madrid: Tecnos.

- 1999. La Inclusión del Otro. Estudios de Teoría Política. Barcelona: Paidós.

- 2000. La Constelación Posnacional. Ensayos Políticos. Barcelona: Paidós.

- 2001a. Más Allá del Estado Nacional. 3rd ed. Madrid: Trotta.

- 2001b. Facticidad y Validez: Sobre el Derecho y el Estado Democrático de Derecho en Términos de Teoría del Discurso. 3rd ed. Madrid: Trotta.

Hegel, G. W. Friedrich 1982. Werke. 12. Vorlesungen über die Philosophie der Geschichte. Frankfurt am Main: Suhrkamp.

Heiberg, Marianne 1989: The Making of the Basque Nation. Cambridge: Cambridge University Press.

Herder, Johann Gottfried 1966. Ideen zur Philosophie der Geschichte der Menschheit. Darmstadt: Melzer.

- 1967. Auch eine Philosophie der Geschichte zur Bildung der Menschheit. Frankfurt am Main: Suhrkamp.

- 1975. Sprachphilosophische Schriften. Hamburg: Felix Meiner.

- 1979. Abhandlung über den Ursprung der Sprache. Stuttgart: Philipp Reclam.

Jover, José María; Gómez-Ferrer, Guadalupe; Fusi, Juan Pablo 2001. España: Sociedad, Política y Civilización (siglos XIX y XX). Madrid: Debate.

Kymlicka, Will 1996. Ciudadanía Multicultural: Una Teoría Liberal de los Derechos de las Minorías. Barcelona: Paidós.

Laín Entralgo, Pedro 2000. Epílogo. In: Real Academia de la Historia, España como Nación. Barcelona: Planeta, 249-253.

Lévi-Strauss, Claude 1958. Anthropologie structurale. Paris: Plon.

- 1962. La Pensée Sauvage. Paris: Plon.

- 1964-1978. Mythologiques I-IV. Paris: Plon.

- 1967. Les structures elémentaires de la parenté. Paris: Mouton.

Llera, María del Mar 2000a. How to ground an intercultural ethics? In: Abstracts of the 1st International Congress on Science and Culture Values. University of León, Spain.

- 2000b. How to come to an agreement? We already agree! Reflections upon an intercultural ethics. In: Abstracts of the VI International Congress on European Culture. University of Navarra, Spain.

- 2001. How to avoid the clash among civilizations: A critical review on Samuel Huntington. In: Abstracts of the VII Conference on Ethnological Approaches in the New Millennium. Société Internationale d'Ethnologie et Folklore. Budapest, Hungary.

Lotman, Juri Mikhailovich 1996. La Semiosfera I. Semiótica de la Cultura y del Texto. Madrid: Cátedra, Madrid.

- 1998. La Semiosfera II. Semiótica de la Cultura, del Texto, de la Conducta y del Espacio. Madrid: Cátedra.

Malinowski, Bronislaw 1923. The problem of meaning in primitive languages. In: Ogden, Charles Kay; Richards, I. A., The Meaning of Meaning: A Study of the 
Influence of Language upon Thought and of the Science of Symbolism. London: Routledge \& Kegan Paul, 451-510.

- 1948. Magic, Science, and Religion, and Other Essays. New York: Doubleday.

Marcuse, Herbert 1969. Cultura y Sociedad. 4th ed. Buenos Aires: Sur.

- 1972. Ensayos sobre Politica y Cultura. 3rd ed. Barcelona: Ariel.

Real Academia de la Historia 2000: España como Nación. Barcelona: Planeta.

Robbins, Derek 2000. Bordieu and Culture. London: Sage Publications.

Rodrigo Alsina, Miquel 1999. Comunicación Intercultural. Barcelona: Anthropos.

Rorty, Richard 1989. Contingency, Irony and Solidarity. New York: Cambridge University Press.

- 1991. Objectivity, Relativism and Truth. New York: Cambridge University Press.

- 1998. Pragmatismo y Política. Barcelona: Paidós.

- 2000. El Pragmatismo, una Versión: Antiautoritarismo en Epistemología y Ética. Barcelona: Ariel.

Rumeu de Armas, Antonio 2000. Consideraciones finales. In: Real Academia de la Historia, España como Nación. Barcelona: Planeta, 241-247.

Silveira Gorski, Héctor C. (ed.) 2000. Identidades Comunitarias y Democracia. Madrid: Trotta.

Solozábal, Juan José 1997. Nación y Estado en la Constitución española. In: De Blas Guerrero, Andrés (ed.), Enciclopedia del Nacionalismo. Madrid: Tecnos, 339-341.

Suárez Fernández, Luis 2000. Hispania: los fundamentos de la nación española. In: Real Academia de la Historia, España como Nación. Barcelona: Planeta, $13-43$.

Unesco 2001. L'Ethique pour le XXIe Siècle (21-22 septembre, rapport). Paris: Maison de l'Unesco.

Uriarte, Edurne 2002. Nación española y nacionalismo español. Revista de Occidente 248: 109-132.

\section{Прагматический подход к межкультурной этике: Основные черты развития коммуникации между национальными группами}

Статья является частью более обширной программы, которая занимается различными аспектами интеркультуральной этики и основывается на принципах Проекта интеркультуральной этики ЮНЕСКО (Intercultural Ethics Project). Цель автора - предложить прагматические средства для анализа актуального для Испании противостояния между пропагандистами испанской и баскской национальных культур. Указывая на исторические корни возникновения этих разных типов самоидентификации, автор приходит к выводу, что как 
“чистая" культура, так и “чистое” национальное государство являются иллюзорными понятиями и что не существует культуры без идеологии (Хабермас). Основной вывод исследования: разрешение конфликта требует от обеих сторон более четкого самоопределения. Только в том случае, если каждая национальная группа способна к четкой самоидентификации, она способна и понять другую группу и вступить с ней в коммуникацию. Если мультикультуральность является фактом современного общества, то интеркультуральность является вызовом. И чтобы с ним справится, нужна коммуникационная практика нового типа, которая опиралась бы не на логику власти, а на рациональность взаимопонимания. Именно основы этой новой логики межкультурной коммуникации автор пытается выявить в данной статье.

\section{Pragmaatilisi lähenemisi kultuuridevahelisele eetikale: Rahvusgruppide vahelise kommunikatsiooni edendamise põhijooni}

Käesolev artikkel on osa laiaulatuslikumast programmist, mis tegeleb kultuuridevahelise eetika erinevate aspektidega ja mis sai algtõuke UNESCO Kultuuridevahelise Eetika Projektist (Intercultural Ethics Project). Autor on seadnud eesmärgiks pakkuda pragmaatilisi vahendeid analüüsimaks Hispaanias aktuaalset kultuurilist ja poliitilist vastuseisu hispaania ning baski rahvuskultuuri propageerijate vahel. Püütakse selgitada vastasleeride identiteedi ajaloolist teket ja jõutakse järeldusele, et nii puhas kultuur kui ka puhas rahvusriik on illusoorsed mõisted ning et kultuuri ilma ideoloogiata ei eksisteeri (Habermas). Uurimuse põhijäreldus on, et konflikti lahendamine nõuab mõlemalt rahvusgrupilt sügavamat enesemääratlust. Vaid juhul, kui kumbki rahvus on võimeline selgelt iseennast piiritlema/määratlema, on ta võimeline teist mõistma ja temaga kommunikeeruma. Kui multikultuurilisus on igas ühiskonnas fakt, siis interkultuurilisus on väljakutse, millega toimetulekuks on vaja uut tüüpi kommunikatsioonipraktikat, mis ei toetuks mitte võimuloogikale, vaid teineteisemõistmise ratsionaalsusele. Just uue kultuuridevahelise kommunikatsiooni loogika aluseid püüabki autor käesolevas artiklis esile tuua. 